\title{
PERSPECTIVES OF THE TRANSITION TO THE DIGITAL ECONOMY IN EU
}

\author{
Angela Albu ${ }^{1 *}$, ORCID ID: 0000-0002-6580-8209, \\ Maria Sabina Albu \\ University "Stefan cel Mare", Suceava, str. Universitatii, no. 13, Suceava, ROMANIA \\ *Corresponding author: Angela Albu, angela.albu@usm.ro
}

Received: 08. 26. 2021

Accepted: 10. 04. 2021

\begin{abstract}
The Fourth Industrial Revolution or Industry 4.0 refers, in simple terms, to the way in which the technologies like artificial intelligence, autonomous vehicles, augmented reality and the internet of things are merging with the physical life of the people all around the globe. This new "era" is expected to transform in a revolutionary way the economies, employment and even the society in which we live today. The digital economy is very different in comparison to the traditional one and it is the result of the accelerated evolution of telecommunications, internet and electronics, and their integration in our everyday life. This arising economy is favoring the development of a new type of business, i.e. e-business. The process of the transformation of the actual economy in a digital one needs a set of favorable factors and a period of time, named period of transition. In this context, it is necessary to understand and to assess how advanced the transition process is in each EU country so that to be able to create and implement the suitable strategies who will lead to the digital economy. At EU level it was create an index - Digital Economy and Society Index (DESI) - with the aim to measure the progress of EU countries towards a digital economy and society. Our paper presents this index and make a comparative analysis of its evolution during the last 5 years. The results show an intense preoccupation of all EU countries for the improvement of the sectors considered in the calculation of DESI and the progress made by some states in this field.
\end{abstract}

Keywords: business environment, digital economy, Digital Economy and Society Index, digital skills, Industry 4.0.

Rezumat. În termeni simpli, a patra revoluție industrială sau Industria 4.0. se referă la modul în care tehnologiile ca inteligența artificială, vehicule autonome, realitatea augmentată și internetul lucrurilor pătrund în viața oamenilor de pe tot globul. Se așteaptă ca această eră nouă să transforme într-un mod revoluționar economiile, locurile de muncă și chiar societatea în care trăim astăzi. Economia digitală este foarte diferită în comparație cu cea tradițională, fiind rezultatul evoluției accelerate a telecomunicațiilor, internetului și a electronicii, respectiv a integrării lor în viața noastră de zi cu zi. Această economie în dezvoltare favorizează noi tipuri de afaceri, cum ar fi afacerile electronice. Procesul de transformare a 
economiei actuale într-una digitală necesită existența unor factori suport și a unei perioade de timp, numită perioada de tranziție. În acest context este necesar să înțelegem și să evaluăm cât de avansat este procesul de tranziție în fiecare din economiile statelor UE pentru a crea și implementa strategii potrivite care să conducă la o economie digitală. La nivelul Uniunii Europene a fost creat un indice - Indicele Economiei și Societății Digitale - cu scopul de a măsura progresul țărilor UE către o economie și societate digitală. Lucrarea noastră prezintă acest indice și realizează o analiză comparativă a evoluției acestuia în ultimii 5 ani. Rezultatul arată o preocupare intensă a tuturor statelor membre ale UE pentru îmbunătățirea rezultatelor dimensiunilor luate în considerare la calcularea indicelui, precum și progresul realizat de unele state în acest domeniu.

Cuvinte cheie: mediu de afaceri, economie digitală, Indicele Economiei și Societății Digitale, competențe digitale, Industrie 4.0.

\section{Introduction}

We are witnesses of a radical transformation of our society with an incredible speed, which change the face of almost everything: industry and technology, economy, society, the way of thinking and making decisions. The world we live in has evolved so much over time that we can say that it has been reinvented. It's amazing how people have learned on their own how to use the resources around them to create something new and grow permanently. One invention led to another and in this way, gradually, we came to be able to achieve almost anything we imagine. The technological revolutions have created the necessary context on which the development of the digital age is based. Although each new technology seems to reach the peak of possible development, each time, a better technology appears. This unstoppable evolution has led to the creation of intelligent, autonomous systems. The economic field is deeply influenced by the digital age, in the sense that, although it began to modernize through the development of production technologies, it came to create a new way of carrying out the production activity through smart factories, improved and expanded the service sector, formulated new business models, brought profitability, added a new market, the one specific to e-commerce, etc. The performance of the digital economy is largely due to the Internet and databases. In this context the assessment of the progress of the digital economy becomes a necessity, due to its valuable information for the future decisions.

\section{Industry 4.0 - the Forth Industrial Revolution}

The concept of the Fourth Industrial Revolution, also called Industry 4.0, was first defined and explained in the book "The Fourth Industrial Revolution" in 2016, by the founder of the World Economic Forum - Klaus Schwab. He best described the phenomenon of the new revolution: of the many diverse and fascinating challenges we face today, the most intense and important is how to understand and apply the new technological revolution, which involves a transformation of humanity. We are at the beginning of a revolution that fundamentally changes the way we live, work and relate to each other. Schwab has provided unlimited possibilities to have billions of people connected via mobile devices, giving rise to unprecedented processing power, storage capacity and access to knowledge. He also named the confluence of several major and startling emerging technological discoveries, covering large-scale fields such as artificial intelligence, robotics, the Internet of Things, autonomous vehicles, 3D printing, nanotechnology, biotechnology materials science, energy storage and quantum computing [1]. The main features of Industry 4.0 include: 
- horizontal integration - through value networks to facilitate collaboration between corporations;

- vertical integration - of hierarchical subsystems inside a factory to create a flexible and reconfigurable manufacturing system;

- integration of end-to-end engineering - throughout the value chain to support product customization.

Although it is a dynamic and on-going process, there were identified and defined the supporting pillars of Industry 4.0 (Table 1 ).

Table 1

The nine pillars of Industry 4.0. concept

\begin{tabular}{|c|c|}
\hline The pillar & Description \\
\hline Big Data & $\begin{array}{l}\text { Represents big volumes of data used for systematic real-time } \\
\text { optimization of processes, identification of production trends, } \\
\text { models and relationships between inputs and outputs that } \\
\text { can be used to improve work platforms. }\end{array}$ \\
\hline Augmented Reality & $\begin{array}{l}\text { Product presentation without the need for the physical } \\
\text { product, real-time transmission of use instruction or repair } \\
\text { instructions for products. }\end{array}$ \\
\hline Simulation & $\begin{array}{l}\text { Have the role of creating a mirror image of the real conditions } \\
\text { that can be used for optimization. }\end{array}$ \\
\hline Internet of Things & $\begin{array}{l}\text { Involves the interconnection of all machines or devices that } \\
\text { enter into a process, even more than that, of the entire } \\
\text { operating system, in order to transmit and receive information } \\
\text { or commands. }\end{array}$ \\
\hline Cloud Computing & $\begin{array}{l}\text { Uses a network of servers to store, manage and process the } \\
\text { data. }\end{array}$ \\
\hline Cyber security & $\begin{array}{l}\text { Ensuring full protection over the most important company } \\
\text { data: manufacturing processes, financial data, suppliers, } \\
\text { prices or other information related to customers. }\end{array}$ \\
\hline System integration & $\begin{array}{l}\text { Involves the linking of computer systems allowing effective } \\
\text { communication and data transmission between them so that } \\
\text { there is coordination between individual systems and work } \\
\text { programs. }\end{array}$ \\
\hline 3D Technology & $\begin{array}{l}\text { Can be used to make prototypes and simple components in } \\
\text { high-tech industries. The products result from the deposition } \\
\text { of successive layers of plastic or metal. }\end{array}$ \\
\hline $\begin{array}{l}\text { Autonomous } \\
\text { Systems }\end{array}$ & $\begin{array}{l}\text { They will act without human intervention, being programmed } \\
\text { and trained in this sense. Robots as autonomous systems will } \\
\text { be able to think and make decisions independently. }\end{array}$ \\
\hline
\end{tabular}

This dramatical change of production processes, economy and whole society brings both benefits and challenges for actual and futures generation. 


\section{Digital economy - a goal to be reached}

Digitization and digital economy are buzz words not only in media environment, but also in the scientific researches, official reports and statistics. The era of digitization started in 90s with the penetration and diffusion of internet in all areas of activities and continuing with other tools and techniques available today on the market for business sector, administration and, generally speaking, for the whole society. Being an emerging concept, with a rapid and multidimensional evolution, there isn't a single definition for the digital economy, the scientific literature providing several. In a broad sense, the digital economy means the use of "Internet Protocol-enabled communications and networks irrespective of industry" [4]. The digital economy differs from internet economy, the last one being included in the first: the internet economy refers to the different economic activities developed with the use of internet, while digital economy needs an extended interconnectivity of networks and an interoperability of digital platforms of all sectors of economy and society. The development of digital economy leaded to a continuously change of patterns of production and consumption, of distribution, promotion and communication between the actors in the business environment and/or in the whole society. The digital economy requires information expressed in a digital manner, but also a shift of way of thinking and labour culture, as well. The conversion of the information to a digital form is called digitization and the process doesn't change the content or the value of the information, only transforms it in a digital document, for an easier access and use with digital tools. More complicate is to change the manner of thinking, the business models or to add new values to the products and services through the digital chain. This approach is called digitalization and refers to the process of using digital technologies to change your business model and to adopt new ones which give more opportunities improving or re-inventing the business and passing into a new era - the era of digital business.

The development rate of digital economy is really impressive, it is estimated a doubledigit annual growth around the world, not only in the North (in the area of developed countries), but especially in the South, according to the World Economic Forum [5]. The countries have different levels of development of digital economy, but the common trends are the interconnectivity of networks, which enables the information traffic to travel across and between networks and the interoperability of operating platforms, which allow the traffic to run effectively across different types of networks. One of the core problems in the field of digital economy is the identification and characterization of the core factors which are influencing the process. The assessment framework is holistic and integrates all levels of digital value chain and the stakeholders involved. The development of the digital economy must take into consideration the following interconnected areas [6]:

a) Physical infrastructure and internet connectivity - this factor deals with the quality of the physical infrastructure for the internet and other devices, with the internet penetration for persons and for businesses and with internet affordability. Despite that the physical infrastructure has improved continuously, there are huge differences between regions, countries and persons; from geographical point of view, the biggest concentrations of users involved in digital economy are in North America and China.

b) Skills and education - refer to the quality of education systems and their capacity to provide knowledge and specific, non-routine skills for the young generation and innovation capacity. In this context, the skills in math and sciences are considered 
fundamentals. Here we can talk about the consumers readiness for digital economy, both for individuals and business consumers and about the digital literacy.

c) Business environment - should be analysed from two perspectives: on one hand, the business environment is the result of the development of the digital economy, reflected in how easy can start a business in the new digital conditions and which are the new business models; on the other hand, the business environment of the digital economy influences offers new opportunities to initiate and manage new business and, in the same time, the companies which are not involved in the digitalization process, are stimulated by the business environment to do it.

d) Access to capital financing and financial infrastructure - taking into account the importance of financing support for all types of development, in the case of digital economy, the financial aspects cover a broad area; in this pillar is included the digitalization of the banks and bank services for the companies, for a better connectivity with the other businesses, but also the access to the capital for the companies interested to invest in their future digital economy. With a secondary importance, it is also included the access of private persons to bank capital for acquisition of products and/or services for their personal use, but connected with digital skills or facilities.

e) Regulatory and legal environment - the development of digital economy has some specific features which must regulated properly. The lawmaking bodies must be effective and keep up with changes. Especially in the field of trade (exports and imports) are needed new procedures for the new type of assets, subjected to be traded.

From the characterization of the areas which support and influence the development of digital economy we can conclude that the there is a strong interdependence between which should be studied and assessed for a better coordination and implementation od strategies in the future. The digital economy represents now a target for almost all the world economies due to the huge positive impact on business environment and society: only in 15 years, between 2005 and 2018, the Global ICT services exports grew from \$174 billion to \$ 568 billion and the employment in ICT sector had an evolution from 34 to 39 million persons [7].

The level of development is uneven; however, all countries are aware that the evolution to a digital economy will affect direct and indirect all the economic and social areas and that there is a lack of methods for measure the impact and value created in the digital economy. There are some statistics and figures about the extent of the sector, but not enough to represent an accurate image of the evolution of the digital economy during last $10-15$ years and to be the basis for future forecasting, policies and strategies creation.

For example, in the Digital Economy Report, released by the United Nation in 2019, there are information about global ICT services exports, global employment in the ICT sector, value added in ICT sector as share of GDP, share of ICT goods trade in total merchandise trade and some other few indicators for which exist information at national and global level.

There is a need to develop methods and tools to measure the digital economy with its multiple dimensions, for a better assessment at local, national and international performance. 


\section{Case study: the assessment of the progress towards a Digital Economy in EU}

At the level of EU there is a high interest in adopting digital economy and there is a set of political and economic measures which support both the business and administrative fields. Also, it was created a composite index - Digital Economy and Society Index (DESI) to measure the progress of EU countries towards a digital economy and society. DESI combines more than 30 indicators and uses a weighting system to rank each country according to its digital performance. The index is divided into five main dimensions, which are further composed of sub-dimensions.

Fast and reliable broadband internet access (including fixed and mobile connections) is defined as a modern and robust digital infrastructure that provides the necessary coverage for these services. Therefore, connectivity measures the implementation of broadband infrastructure and its quality.

Human capital consists of people's digital skills that are the backbone of the digital society. This type of skills is needed in order to take advantage of the opportunities offered by a digital society and allow people to use digital services and engage in basic online activities. Basic and advanced digital skills need to be implemented in school curricula and academic offerings in EU countries.

The third dimension is named: The use of internet by citizens refers to the variety of activities carried out by citizens online. The use of the Internet by people has been increasing since its inception, by expanding the possibilities of the population to access the Internet and by developing networks and internet needs.

The integration of digital technology in enterprises refers to the digitalization of business and the development of the online sales channel, these being techniques adopted by more and more companies today. One of the obstacles is the inability of small and medium-sized enterprises is to move to digitalization, which is caused by low levels of digital literacy among owners, managers and employees. The diminish of these deficiencies will be vital in order to ensure the recovery of existing gaps, so that their development in the digital age becomes possible.

Digital public services: on the public services side, digitalization is gaining power, with a particular focus on e-government.

Some of these dimensions, sub-dimensions and some individual indicators are more relevant than others, that is why they have been given a higher or lower weight in calculating the final score of the index for each country. Connectivity and human capital are considered the most relevant dimensions that reflect the priorities of EU digital policy, as they represent the infrastructure of the digital economy and society. Therefore, they were assigned with the highest percentage of $25 \%$. The integration of digital technology captures the use of ICT by the business sector, being one of the most important growth factors and having a medium share of $20 \%$. Finally, the use of the Internet by citizens and digital public services are possible due to infrastructure, and their contribution is enhanced by the quality of such infrastructure. For this reason, they have a lower share of $15 \%$.

The DESI scored for country is calculated using the formula:

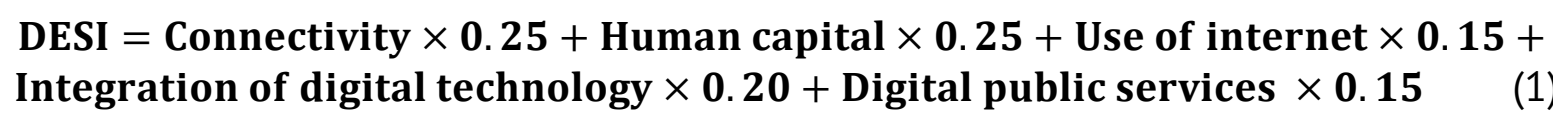


All the sub-dimensions values are normalized to be between 0 and 100 , where 100 is the best performance.

The value of EU's DESI index is given by the value average of the Member States, each state's value being formed by summing the 5 dimensions of the index, resulting in the level of digital performance of each country compared to the EU average. In 2019, the situation of the DESI index for the 28 EU Member States is presented in Figure 1.

The figure below shows that Finland, Sweden and Denmark are countries with outstanding results in terms of overall digital performance. Of course, this is partly due to their very good level of general development as a state, ranking first in many reports. Therefore, they can afford to invest more than other countries in the area of digital systems and technologies.

\section{DESI index level for the member states compared to the EU's average in 2018}

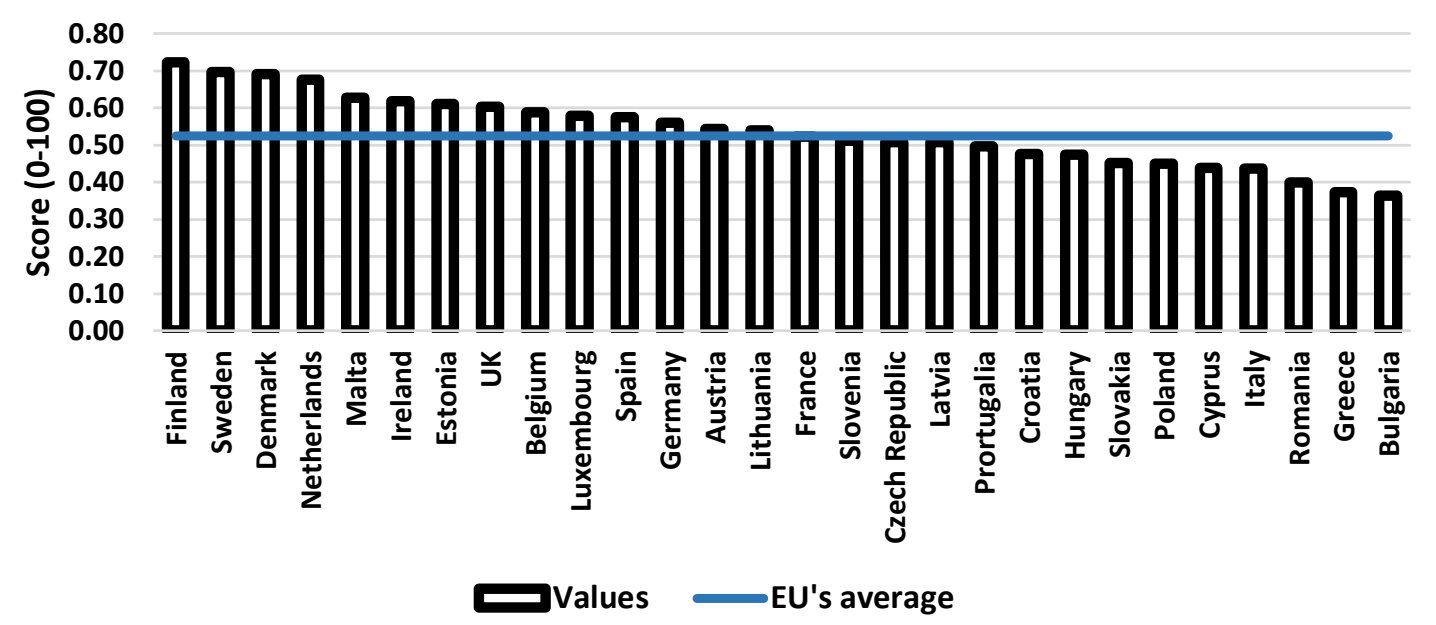

Figure 1. DESI index level for the member states compared to the EU's average in 2019. Source: own elaboration with information from [8].

Performance's values are in the general range of 0 to 100 from the maximum value of 72.30 to the minimum of 36.43. As an average value of the 28 states, the EU reached the level of 52.57, in 2019, being equal to that of France. Lithuania, Austria and Germany are the countries with very close values, but slightly higher than the EU average. They also have a good level of development but haven't developed yet enough digitization's dimensions to be at the top. Slovenia, the Czech Republic, Latvia and Portugal are below the EU average very close to it, and they are also less developed countries than those presented previously. At the bottom of the ranking are Romania, Greece and Bulgaria, developing countries, show a slower integration of digitalization in their economic and social systems. However, this situation, built on the data collected from 2019, can change at any time, the forecasts of specialists claiming that a continuous increase of digital performances for all states is expected.

The latest DESI Report, published by the European Commission in 2020, provides data to analyze the evolution of the EU's global DESI index, on the 5 dimensions of the index, over the last 5 years. Figure 2 presents this evolution. 


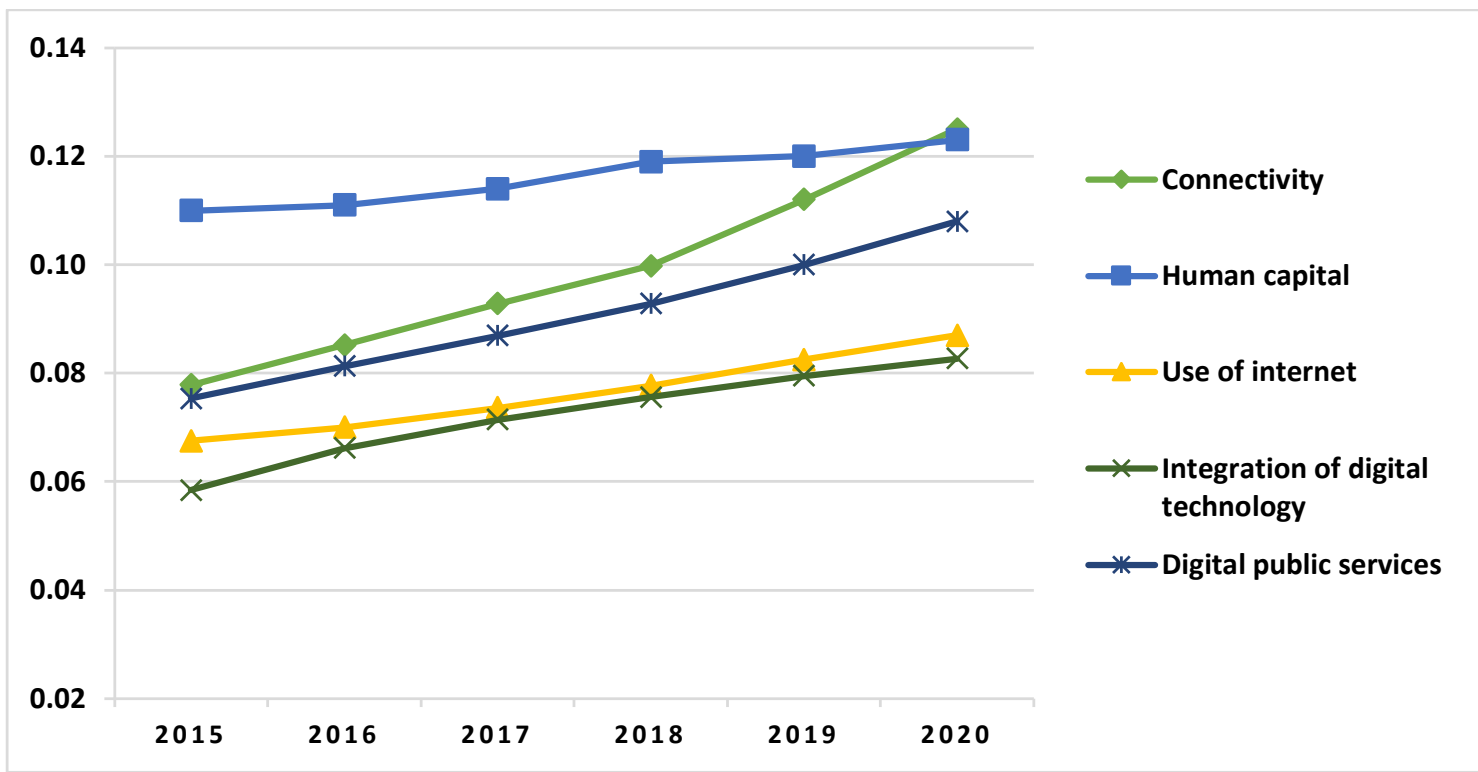

Figure 2. Evolution of DESI global index dimensions at the EU's level in 2015-2020 period.

Source: own elaboration with information from [8].

We can see from the graph the continuous development of EU's dimensions from the fact that there is no situation in which a value would fall below the previous year's value. Human capital is the dimension that started in 2015 with the best value and had a process of slight growth, and then, a stability period starting with 2018. Connectivity recorded an accelerated growth from the beginning, starting from a value of 7.78 and reaching 12.5 , the highest value of all the dimensions of the DESI index. This growth became almost abrupt with 2018, which seems to have had a major impact on both dimensions. The performance of digital public services has increased steadily over the years, starting near connectivity but not having the same change of slope in 2018. The use of Internet and the integration of digital technology in businesses are the last two dimensions, close together, showing a slight and almost parallel ascent. They are at a great distance, around 5 units, from the size of human capital every year, but they are still growing, so these are the sectors that need improvement.

\section{Conclusions}

The digitalization of the economy is expanding more and more and is considered very important today for the internal economic and social development of each state. The EU faces a strong competition with USA and China and needs more investments in infrastructure for digital economy and in education systems to assure the digital literacy of future employees. The actual situation shows a good start and a good evolution for connectivity and human capital dimensions form DESI structure and a lower evolution for the other three dimensions. The forecasts are positive, according to the concept promoted by the United Nations that in the future, digital economy must be for the many, not just for the few; the individuals and small business will contribute to the rapid growth and profitability, but, in the same time, the business environment should remain open to the changes in the business models, adapted to the new reality specific to digital economy. 


\section{Bibliography}

1. Schwab K. The Fourth Industrial Revolution, World Economic Forum, Geneva, (2016), https://books.google.ro/books?id=ST_FDAAAQBAJ \& printsec=frontcover \&dq=inauthor:\%22Klaus+Schwab\%2 2\&hl=ro\&sa=X\&ved=2ahUKEwjFmsḦ-6LXqAhWFlosKHQQkBZoQ6AEwAHoECAYQAg\#v=onepage \&q\&f =true

2. Parviainen P., Tihinen M., Kääriäinen J. și Teppola S. Tackling the digitalization challenge: how to benefit from digitalization in practice, International Journal of Information Systems and Project Management, Vol. 5, nr. 1, 2017, pp. 63-77, http://www.sciencesphere.org/ijispm/archive/ijispm-0501.pdf\#page=67

3. Gillich E.V., Mocan M. Cei nouă piloni ai noii revoluții industriale - Industry 4.0, Conferință internațională multidisciplinară, Ediția a XVII-a, Sebeș, 2017, disponibil la http://stiintasiinginerie.ro/wpcontent/uploads/2017/05/10.-CEI-NOU\%C4\%82-PILONI-AI-NOII-REVOLU\%C5\%A2II-INDUSTRIALE\%E2\%80\%93-INDUSTRY-4.0-Edwald-Viktor-GILLICH-Marian-MOCAN.pdf

4. ISOC, Unleashing the Potential of the Internet for ASEAN Economies, 2015, https://www.internetsociety.org/sites/default/files/ASEAN_ISOC_Digital_Economy_Report_Full_O.pdf

5. WEF, "Expanding Participation and Boosting Growth: The Infrastructure Needs of the Digital Economy", World Economic Forum, Geneva, 2015, http://www3.weforum.org/docs/WEFUSA_DigitalInfrastructure_Report2015.pdf

6. AVASANT LLC, The Development of the Digital Economy. A Framework to Bridge the Digital Divide and Reap Digital Dividends, 2016, https://avasant.com/research-reports/

7. UNITED NATIONS, Digital Economy Report, 2019, https://unctad.org/system/files/officialdocument/der2019_en.pdf

8. EUROPEAN COMMISSION, Digital Economy and Society Index 2020. Thematic chapters, 2020, https://ec.europa.eu/digital-single-market/en/digital-economy-and-society-index-desi 